\title{
Why Not Teach the History of the Universe?
}

TET me begin, asking your forbearance, 1 with an extract from the Iowa Clarion of Apr. 18, 2147, reporting a conference or symposium held by a number of historians at Iowa City.

Speaking before a selected group of world officials in the Auditorium last night, Professor Howie Notall Binns of Mackenzie University declared that schools and universities should stop teaching the history of the world, and concentrate instead upon the history of the universe. "Unless we understand the abnormal-I might even say the utter-irrationality of the inhabitants of Venus," he maintained, "we shall never be able to deal satisfactorily with similar irrational elements in our own people." Professor Binns went on to say that world federalism could not continue to succeed without careful scrutiny and application of the principles worked out in the long-established federation of the moons of Jupiter, and that our knowledge of overlapping and interlocking historical cycles, a study admittedly in its infancy, would be forwarded to a measurable extent, to our own consequent advantage, by detailed analysis of the successful predictions practised and made use of in connection with the rings of Saturn. "In comparison with the fine results which these older communities have obtained in the control of both human and physical nature," Professor Binns concluded, "we are groping in the dark almost as helplessly as we were two centuries ago."

Professor U. N. Tchuno of the University of Argentine feared that universal war and the end of our civilization might well follow our failure to extend our history courses outside our own puny world limits. "We are now dealing with people," he cried, "who

1 Paper presented Apr. 19, 1947, at the Iowa State Historical Conference held by the University of Iowa at Iowa City. have never had either a Marx or a Ford, and it is absurd and dangerous for us to continue to waste the precious time of our children by telling them of either. I count 3118perhaps 3119-civilizations in the history of the universe that have flourished and failed; unless we can discover the reasons for those failures, we shall assuredly end by failing ourselves."

Other members of the audience supported these sentiments, with the exception of a single speaker, afterwards discovered to be one Henry Jefferson of Liberty, Iowa, who was understood to remark that he thought something might be said for teaching Iowa children the history of Iowa. "History begins in our own back yard," those nearest him told reporters they fancied they heard him say before he was placed under arrest and removed from the hall.

An editorial the following day in the great Yukon Aurora, considered to have become, since the artificial melting of the polar ice fields through atomic energy, the leading paper of the Western Hemisphere, read as follows:

Some two hundred years ago, after the close of the second of the world wars which convulsed the twentieth century, a courageous group of historians and publicists challenged the primitive practice then in vogue of teaching what was known as American history in the schools. The long and bitter discussion which ensued, in the course of which the defenders of "American history" naturally aligned themselves with the proponents of a narrow nationalism, was not concluded until the police powers of the new world state were invoked. Since that time, now more than a century ago, history as taught to the children of the world has been a powerful inducement to world order and tranquility. The Board 
of Historical Control, a department of the well-known O.W.K. (Office of World Knowledge), has supervised the training of teachers and the publication of textbooks. Its rigid system of school and college inspection has become a model which other departments are striving to emulate. The unfortunate incident which occurred in Iowa City last night should not be regarded as a reflection upon the B.H.C. A few unassimilated elements, as harmless as they are unbalanced, are doubtless to be found in many areas throughout the world.

The primary task before the world state, as the Aurora has consistently advocated, is the preservation of universal harmony. We have no hesitation in recommending to O.W.K. serious consideration of those measures presented so ably last night at Iowa City.

With that influential recommendation the editorial ends, and with it this first venture of mine into the tempting field of Utopiamaking.

\section{Wrongness of Philosophy}

It is probably unnecessary to explain to any group of historians just what is wrong about the very logical philosophy of history advanced by Messrs. Binns and Tchuno and even more by their journalistic contemporary, the Aurora. For the three of them, history has at last become one of the social sciences, through the directed use of which human beings can be shaped for the achievement of political ends. The professors, I am pleased to report, still believe in true history-finding out what did happen in Venus-though I fear they also lend their approval to the repugnant processes of statedirected selectivity and dissemination of historical interpretations to which the Aurora is so irrevocably committed. I am also moved by the fact that two centuries hence some measure of free speech still exists. Members of the audience could still express opinions, and Henry Jefferson could scarcely have been the only man in Iowa to show some sentiment, and some understanding of the validity and importance of his sentiment, for the land which he and his fathers had tilled.

In my opinion, history is not one of the social sciences, any more than is music or poetry, and calling it so, and thinking of it so, and teaching it in connection with economics and sociology and psychiatry, as they are conceived today, is one more contribution to the advance of the jungle. You people in Iowa have not seen once productive fields giving way, as in parts of New England, to the wilderness. Subtly, almost imperceptibly, the junipers, the soft woods, the vines creep in, beginning at the edges of the fields and seeding themselves further each season. The man who wants to save one small grass plot, one garden, or one small orchard, must keep wielding the mattock and the ax. Those once productive cultural fields of our Western civilizationthe concept of a possible society made up of free, rational, self-disciplined human beings, each one an end in himself, and fulfilling his own peculiar potentialities through service in greater or smaller degree to the community -in upon these fields the jungle is being let. Any observant man, setting himself to look for such evidence, can find it on every side.

\section{Knowledge of Past}

We are here concerned with only one of those sides, which has to do with men's knowledge of their past. Recorded history is an extension of one's own experience to the experience of other human beings like ourselves who did the same things we do, though with varying ideas and under varying institutions. This is at once the simplest and the most human and most productive way of regarding history. So regarded, history becomes one means of keeping alive an individual's belief in himself and in 
individualism, of helping him select his own historical facts, come to his own conclusions, and so develop his own philosophy of living, of which his interpretation of history forms an essential, integral part. History regarded as social science must inevitably tend towards the standardization - or better, the impersonalization - of interpretations and of the philosophies which arise from them. It destroys that very thing which is the strength and the essence of history: individual differences of opinion based upon the obvious fact that individuals are different. Not the weakness of history, as some social scientists are fond of pointing out, but its glory, lies in such disagreements as Howard Beale revealed in his article on the causes of the Civil War as interpreted by historians, in the recent report of the committee on historiography, written under the auspices-I hate to admit it—of the Social Science Research Council.

The function of the teacher of history, therefore, is to help his students extend their own experiences, nothing else. The moment he starts giving a dogmatic interpretation of his own, especially on those great questions like the Civil War and the fall of the Roman Empire, he sells out to the jungle. When he teaches no interpretation but his own, insists on it, will let no student hazard any other, he is already fit for the staff of the Yukon Aurora.

The place to start the teaching of history in this broad and human sense is exactly where Henry Jefferson put it, "in our own back yard," in the prairies and corn fields, which are the Iowa version of New England rocks and rills. Midwesterners are woefully ignorant of Midwestern history.

\section{Midwestern History}

A few months ago, a speaker in St. Joseph, Mo., on the occasion of the hundredth anniversary of the chartering of the Hannibal \& St. Jo railroad, told something about the courage and hopes of the men who began it, about its importance to northern Iowa, and of its dramatic significance in the days when all freight and mail, going West, was funneled along that narrow strip of track. At the end of the speech, an intelligent young woman came up and said, "I didn't know that was history. I didn't know the Midwest had a history. I thought history was Plymouth Rock and Bunker Hill." That tragic story illustrates the meaningless results of teaching historical abstractions in a vacuum unrelated to experience. What sense does a Bostonian's view of the United States make to someone from St. Jo? Boston children can be taught about Bunker Hill; all of them have seen the monument and, if they are willing to take their lives in their hands, they can see in the middle of a busy street the cobble-stoned circle which marks the site of the Boston Massacre. An imaginative teacher finds it easy to put a bewigged royal governor on the balcony of the Old State House above that circle, and from there to develop the conflict between Massachusetts and the Crown. The equivalent for St. Jo is Roubidoux's cabin, the pageant of canoes - missionary, Indian, fur trader-on that swift broad river, the steamboats, the Gold Rush, the railroad, the settlers, the Civil War-every one of which ties St. Jo to the rest of the country and the rest of the world.

A couple of months ago the Chicago Sun asked the Newberry Library to edit a special Midwestern edition of its literary section, "Book Week," to appear May 4an issue to be devoted to a series of bibliographical articles which would suggest the best books for the intelligent layman who wanted to learn something about the Midwest. The guest editor invited a number of experts in various fields to contribute 
articles. They are good articles, for the most part, but they leave anyone who believes in the value of history a little sad. There are simply not enough books that meet the triple standards of accuracy, readability, and sympathy for the subject.

\section{Cities of the Midwest}

Take, for instance, the great city. The Midwest has eight or nine large cities, and the paucity of material on them is pathetic. Compare what has been written about Chicago with what has been written on London or Paris, even after making due allowance for Chicago's youth. There are books on every square in London, on streets, on buildings, and they are being published all the time. One of the most recent is on the natural history of London, beautifully illustrated, written by a naturalist who can tell you what plants grew where two centuries ago and what ones have disappeared, what birds have come and have left the city and which ones remain. An English historian walking along the South Downs with an American companion and seeing a row of beehives in the valley below, remarked, "There were beehives there in Domesday Book." The unity of past and present, the dropping away of the centuries, the identifying of one's own experience with the experience of countless individuals who have gone before- everything that the historian wants who sees history as philosophy, is in that remark. We don't know enough about the Midwest to know it that well.

Again, there are no surveys such as a competent sociologist can make-and even the historian who denies that history should be a social science can find useful material in such surveys - of any Midwestern city except Chicago. Louis Wirth has directed a number of studies of parts of Chicago, but he is the first to say that not only has Chicago nothing like Charles Booth's enormous study of Life and Labour in London; it has not even anything approaching Henry Mayhew's four volumes on London in the I86o's.

\section{Fewer Books on the Midwest}

We are turning out fewer books on the Midwest today than we did sixty years ago. If you walk up and down looking at the Midwest shelves of a good library, you are impressed with the number of county histories compiled in the nineteenth century, put out for a commercial purpose, I admit, but better than all but one or two of the few twentieth-century county histories; you are impressed with the histories of towns, the number of magazines that dealt with local history, the pioneer accounts, the autobiographies. The new books stand out like a single black-eyed Susan in a field of mustard-they are so few. And as for the firstrate new books .... it's an event when one appears. Graham Hutton's Midwest at Noon is as unique as it is unusual; even though an Englishman can see some things in the Midwest which escape those who have always lived among them, we ought not have left the entire field to him. The Lynds' two books on Middletown have now been followed by one on Plainville, U.S.A., a little out of the real Midwest belt, but to the best of my knowledge no one has tried to repeat for his own section that wholly charming and delightful book on the Rock River by Colonel Phalen called Sinnissippi. For the small town and the farm, as well as the city, we have to depend upon novels, some of them first-rate, like Ruth Suckow's Iowa Interiors or Herbert Quick's trilogy. But novels, though they give us the flavor and the social setting perhaps more faithfully than a history can, do not take the place of factual, interpretative histories. For information on many towns absolutely the only place to go is the 
W.P.A. Federal Writers Project series of state guides. If any of you have looked through the raw materials out of which the guides were written, as I have done for Illinois, you know how inadequate and unscholarly much of that material is. Once in a while there is a good article in the two hundred odd cubic feet of typewritten copy turned out by the W.P.A. workers, but most of it is both badly written and undocumented.

One reason why such books are not being written is that people are not interested, have never been taught to be interested. But another is the increasing scarcity of documentary materials. Take, for example, and it is another Chicago example, because I know more about Chicago's needs than Iowa's, that most interesting period in Chicago's history, the I89o's, when a tough merchants' town suddenly acquired within the space of a few years a great new university, an art gallery, a symphony orchestra, a couple of libraries, and began a new literary movement. Those were the days when, in the local idiom, Chicago made culture hum. What was the reason for it? A young Yale student, a Chicagoan, investigating the question, came to the conclusion that one man, Charles Hutchinson, probably had as much to do with all these developments as anyone. We inquired about the Hutchinson papers, learned that a few years ago they had been destroyed by his surviving heirs; all, that is, but a handful. When telling a dinner companion one night about this tragedy, I was delighted to hear him say, "Why, I've got Charlie Hutchinson's papers. I saved all there are left." These few papers are all that remains of a man, except the institutions he encouraged, whom many people called the leading Chicago citizen of his time. No one can ever write a life, a good one, of Marshall Field or of Potter Palmer or of almost any one of a dozen great nineteenth-century Chicagoans. A friend of mine writing a life of Cleveland's chief justice, Melville Fuller, a Chicago lawyer, finds it almost impossible to get what he wants on Fuller's Chicago career. There may be collections of papers for half a dozen men in those years of the city's spectacular growth; we have more information on men in almost any medieval city than on men in Chicago, the metropolis of the American heartland, which today produces nearly half the manufactures and more than half the food in the United States.

\section{Lack of Documents}

Leave the men for a moment. Turn to the growth of Midwest business. Once a month or more some public relations officer of a Chicago or Midwestern firm has asked my help in getting a substantial history of the business written. It is a centenary ; they are willing to let a good historian write his own ticket, give him all the aid they can, a free hand to go where he wants for facts and to say what he wants-all the essentials as a historian sees them, in short, but one. They have no documents. When it is pointed out to them that no one can write a history without documents, the basic skeleton record of the business as found in the minute books, in the journals and ledgers, and in the correspondence of the chief executives, they reluctantly, sometimes half suspiciously yield, wondering why enough cannot be got out of the newspapers. This is only another example of the absence among Midwesterners of historical-mindedness. One expects it perhaps among ordinary people, like the woman who, cleaning her attic the other day, found and brought in three small books which she hoped might be of value. One of them was a nineteenthcentury pocket edition of Shakespeare, worth perhaps ten cents if it had been in 
good condition. She was descended from the Chase family of Michigan, who had settled there in the 1830 's, and that morning she had burned a bushel-basketful of letters from one of the great pioneer bishops of the Midwest, Philander Chase, founder of Kenyon College. Such destruction goes on daily. Publicity, I think, would help to stop it, and there is no better publicity than that given by school teachers teaching the history of Iowa and the Midwest and working in conjunction with historical societies and college and university libraries.

I have spoken of the paucity of books on the city, small town, farm, individuals, businesses. Look at the history of literature in the Midwest. We have long talked about a Chicago school of writers; there is no book on the subject where there could well be half a dozen. Have you any good book on the Iowa school of writers? Have you any books on Iowa novels and Iowa poetry of the nineteenth century, or on Iowa publications? The Palimpset contains a number of articles on such subjects, but what about books. Is there any study of Iowa architecture? or Iowa presses? of the Iowa theatre? of newspapers? What about a history of political ideas in Iowa, utilizing among other sources those amazing records, the constitutional conventions of the nineteenth century, which sound dull beyond words but are fascinating and lively reading when you bear in mind that in few other countries could as much sound political wisdom have been found as among these Iowa farmers?

Such books need writing, and in a style that will attract readers. It is becoming increasingly obvious that we have two sorts of people doing histories today: the scholar who digs for the facts, can be trusted to turn them up, and whose books are read only by other scholars or would-be scholars; and the professional writer whose sentences have pace, who catches and transfers to the printed page the drama and color of past events, but whose facts and interpretations cannot be believed because he will not dig. These two ought to be the extremes, with plenty of people in the center. The number of writers both sound and readable rattle around in the center like seeds in a gourd.

\section{Lack of History Books}

Here is another reason, then, for the failure of Midwesterners to know themselves. Children in the Chicago public schools are expected to study the history of Chicago at one point in their wobbling career, but there is no history of Chicago they can read. Every so often I get a sad little note from some child asking me to send her some books on Chicago. You have a history or two on Iowa, I know. Are they the kind of histories that, catching the imagination, also initiate a child into the mystery, yet not too involved a mystery, which study of the past teaches: that, though they are individuals, they are also part of the stream?

\section{Tragedy of Twentieth Century}

Everything that $\mathrm{I}$ have been saying is one man's guess at a solution for what must seem to any historian one of the tragedies of the twentieth century. Here is a great people, powerful beyond belief and committed to the political theory that the important decisions of government, in domestic and foreign affairs, must be also the decisions of the majority. Those decisions, during the last twenty-five years, have been, to use the kindliest word, erratic. If they continue to be as erratic for the rest of the century, we shall be known as the people who achieved both the greatest success and the greatest failure in history. Almost any real historian, even a prejudiced one, knows

(Continued on page 426) 
according to subject and speaker. By far the greater percentage of the audience consists of staff, faculty, and graduate students, with never more than a handful of undergraduates except when music or films are featured, and even then university personnel and graduates predominate. This may be partially due to the fact that all dormitories and organized houses serve dinner at half-past five, but experimentation with four-thirty to five-thirty meetings for the Library Hour did not show any difference.

The committee has also discovered that the size of the audience is no criterion of the success of the individual program. One of the best examples of this fact was a talk on the cooperative movement which drew only about twenty people. These twenty, however, engaged the speaker in a lively discussion which lasted about half an hour after he had finished his lecture.

The Library Hour program correlates with another of the public relations programs of the university-"The Library
Presents-," a weekly half-hour radio program over the local university station. The radio and lecture programs are frequently able to make use of each other's speakers.

As a whole, the librarians' association feels that the Library Hour has more than justified the rather considerable work involved. In addition to the value of the program as a source of information to about 2000 different people over a period of two years (a total of approximately 3500 have attended), it has also taught the various committee members a great deal about the workings of the university-its departments and its personalities.

While a large university with its wealth of talent is a reasonably easy field for a series of this sort, it is probable that an even greater need might exist in a smaller school where there are fewer outside events. In any case, such a series, if well planned and publicized, can do much to foster the goodwill of faculty and students toward the library and its staff.

\section{Why Not Teach the History of the Universe?}

\section{(Continued from page 4I3)}

what we lack-a sense of continuity and of balance and understanding of human beings organized into societies that move through time. He knows also the remedy, which is historical-mindedness.

In suggesting that historical-mindedness begin at home, in the back yard, I do not mean that it should stay forever in the back yard. There is a front yard too, and the street which passes by leads to the ends of the earth. Every Iowan ought to follow that street as far as his time, his interest, and his sense of duty propel him. If, at last, it leads him to the rings of Saturn, I am all in favor of it. Why not teach the history of the universe? But not at the outset, not as an abstraction, not until, knowing the history of Iowa, he has history in his blood.

\section{Correction}

In the July issue, Part I, p. 259, it was stated in the article on "College and University Library Statistics" that the previous statistics had been published in the March 1943 issue. It should have read "March 1944." 